\title{
Спеціальність Громадське здоров'я у закладах вищої освіти України: перспективи і шляхи впровадження
}

\author{
УдК 504: 339.9 \\ Є. В. Іммас, С. М. Футорний, І. В. Уряднікова, \\ о. В. Маслова
}

Національний університет фізичного виховання і спорту України, Київ, Україна

\begin{abstract}
Анотація. Мета. На основі аналізу наукової, науково-методичної літератури та інших джерел інформації визначити перспективи впровадження спеціальності «Громадське здоров'я» у закладах вищої освіти України. Методи. Системний аналіз наукової, науково-методичної літератури та інших джерел інформації з питань необхідності впровадження спеціальності «Громадське здоров'я» у закладах вищої освіти України; узагальнення, синтез, формалізація, абстрагування. Результати. Встановлено, що у 2017 р. спеціальність «Громадське здоров'я» вперше з'явилася в Україні та була ліцензована у 2018 р. Її поява викликана необхідністю проведення медичної реформи та підготовки нових кадрів за європейськими стандартами у сфері управління та охорони громадського здоров'я, впровадження загальнонаціонального принципу «охорона здоров'я в усіх політиках держави». Підготовка фахівців у даному напрямі здійснюється за спеціальністю 229 Громадське здоров'я (галузь знань - 22 Охорона здоров'я) на трьох ступенях освіти: бакалавр, магістр і доктор філософії. Спеціалізації за даною спеціальністю: «Промоція здоров'я»; «Менеджмент здоров'я»; «Епідеміологія та біостатистика». Висновки. Встановлено, що Концепція розвитку системи громадського здоров'я в Україні передбачає запровадження у закладах вищої освіти за базовими спеціальностями програм з науково обгрунтованої професійної діяльності в сфері громадського здоров'я для забезпечення проведення комплексної оцінки і моніторингу стану здоров'я населення, виявлення факторів, що впливають на здоров'я населення, здійснення заходів щодо збереження та зміцнення здоров'я населення і оцінювання їх ефективності. Показано, що розробка і впровадження підготовки фахівців за освітньою програмою 229 «Громадське здоров'я» на базі Національного університету фізичного виховання і спорту України є актуальною і перспективною. Визначено, що фахівці із спеціальності «Громадське здоров'я» мають широкі перспективи успішно розпочати кар'єру у міжнародних проектах, недержавних організаціях чи урядових структурах політичної, економічної та соціальної діяльності у напрямі охорони здоров'я.
\end{abstract}

Ключові слова: здоров'я, охорона здоров'я, громадське здоров'я, заклади вищої освіти, перспективи.

Public Health specialty in higher education institutions of Ukraine: prospects and ways of implementation

\section{V. İmas, S. M. Futornyi, i. V. Uriadnikova, O. V. Maslova}

National University of Physical Education and Sport of Ukraine, Kyiv, Ukraine

Abstract. Objective. Based on the analysis of scientific, scientific and methodological literature and other sources of information, determine the prospects for introducing the specialty «Public Health» in higher education institutions of Ukraine.

Methods. Conducting a system analysis of scientific, scientific and methodological literature and other sources of information on the need to introduce the specialty «Public Health» in higher education institutions of Ukraine. The methods of theoretical analysis of scientific literature are used: generalization, synthesis, formalization, abstraction.

Results. It was established that in 2017, the specialty «Public Health» first appeared in Ukraine and was licensed in 2018. Its appearance was caused by the need to carry out medical reform and train new personnel according to European standards in the field of 
public health management and protection, and introduce the national principle of «healthcare in all state policies». The training of specialists in this direction is carried out in the specialty 229 Public Health (area of knowledge - 22 Health) at three levels of education: bachelor, master and doctor of philosophy. Specializations in this specialty: «Health Promotion»; «Health Management»; «Epidemiology and biostatistics». Conclusions. It has been established that the Concept for the development of a public health system in Ukraine provides for the introduction of programs in higher education institutions for basic specialties on scientifically based professional activities in the field of public health in order to ensure a comprehensive assessment and monitoring of the state of public health, to identify factors affecting public health, and to implement measures to preserve and strengthen public health and evaluate their effectiveness. It is shown that the development and implementation of training for specialists in educational program 229 «Public Health» on the basis of the National University of Physical Education and Sports of Ukraine is relevant and promising. It was determined that specialists in the specialty «Public Health» have broad prospects for successfully starting a career in international projects, non-governmental organizations or government structures of political, economic and social activities in the field of healthcare. Keywords: health, healthcare, public health, higher education institutions, prospects.

Постановка проблеми. На сьогодні погіршення стану громадського здоров'я в Україні $\epsilon$ наслідком кризи в усіх сфрерах життєдіяльності: старіння населення, бойові дії на Сході країни, Чорнобильська катастрофра, поширення нездорового способу життя. За даними $\mathrm{OOH}$, станом на 2019 р. кількість населення України становить 43,99 млн осіб і в перспективі до 2050 р. буде невпинно скорочуватись та становитиме 36 млн [1]. Медична реформа, яка впроваджується в Україні, може сприяти виправленню ситуації, що склалася в медичній галузі.

Розпорядженням Кабінету Міністрів України від 30 листопада 2016 р. № 1002-р схвалено Концепцію розвитку системи громадського здоров'я в Україні [2]. Це означає, що ухвалення документа запроваджує процес стратегічного планування розвитку системи із залученням зацікавлених сторін, планування заходів на національному, регіональному та місцевому рівнях. Схвалення Концепції наблизить практичну реалізацію завдань збереження здоров'я та повноцінного життя людей як однієї із найважливіших цілей світової спільноти, відображених у засадах європейської політики «Здоров'я-2020: основи Європейської політики в підтримку дій держави і суспільства в інтересах здоров'я і благополуччя» та в Угоді про асоціацію між Україною та ЄС.

Реалізація цієї Концепції сприятиме створенню ефективної системи розвитку людських ресурсів у сорері громадського здоров'я, що передбачає:

- визнання кадрового забезпечення як невід'ємної частини розвитку сорери громадського здоров'я;

- розроблення і реалізацію стратегії розвитку кадрових ресурсів, у тому числі визначення реальних та прогнозних потреб, планування і здійснення підготовки кадрів, раціонального розподілу, управління ресурсами;
- редормування системи додипломної та післядипломної підготовки працівників системи громадського здоров'я та їх безперервного професійного розвитку, запровадження спеціальності та спеціалізації «громадське здоров'я»;

- навчання за окремими магістерськими програмами у закладах вищої освіти (3ВО), на курсах підвищення кваліфікації або дистанційно фрахівців, які працюють у сфері громадського здоров'я;

- запровадження у ЗВО за базовими спеціальностями програм з науково обгрунтованої профе-сійної діяльності в сфрері громадського здоров'я з метою проведення комплексної оцінки і моніторингу стану здоров'я населення, виявлення факторів, що впливають на здоров'я населення, здійснення заходів щодо збереження та зміцнення здоров'я населення, оцінювання їх ефективності.

Реалізувати Концепцію передбачається протягом 2017-2020 рр. Впровадження Концепції дасть можливість розбудови системи сорери громадського здоров'я в Україні, у тому числі для комплексної рефрорми системи охорони здоров'я [2].

3 огляду на сказане, впровадження спеціальності «Громадське здоров'я» у закладах вищої освіти України і підготовка цих спеціалістів у спортивній галузі $\epsilon$ актуальною і перспективною.

Зв'язок роботи з основними науковими програмами, практичними завданнями. Дослідження пов'язане 3 важливим практичним завданням, а саме визначенням доцільності впровадження підготовки фрахівців за освітньою програмою 229 «Громадське здоров'я» на базі Національного університету фрізичного виховання і спорту України.

Мета дослідження - визначити перспективи і шляхи впровадження спеціальності «Громадське здоров'я» у закладах вищої освіти України.

Методи та організація дослідження. Системний аналіз наукової, науково-методичної 
літератури та інших джерел інфоормації з питань необхідності впровадження спеціальності «Громадське здоров'я» у закладах вищої освіти України; узагальнення, синтез, формалізація, абстрагування.

Результати дослідження та їх обговорення. Громадське здоров'я (англ. Public health) це наука та практика попередження захворювань, збільшення тривалості життя і зміцнення здоров'я шляхом організації зусиль суспільства [1].

Система громадського здоров'я - комплекс інструментів, процедур та заходів, що реалізуються державними та недержавними інституціями для зміцнення здоров'я населення, попередження захворювань, збільшення тривалості активного та працездатного віку, заохочення до здорового способу життя шляхом об'єднаних зусиль усього суспільства [1].

Проведений аналіз наукової та науково-методичної літературисвідчить, щогромадськездоров'я - популярна спеціальність найкращих американських та європейських університетів, таких, як «Університет екології та управління» (Варшава, Польща), Університет лінгвістики «Wszechnica Polska» (Варшава, Польща), Університет суспільно-природничих наук ім. Вінцента Поля (Люблін, Польща), Ченстоховський політехнічний університет (Ченстохова, Польща), Чеський технічний університет (Прага, Чехія), Карлів Університет (Прага, Чехія), Університет св. Кирила та Мефодія у Трнаві (Трнава, Словаччина), Університет Коменського у Братиславі (Братислава, Словаччина), Університет Дебрецені (Дебрецен, Угорщина), Маастрихтський університет (Маастрихт, Нідерланди), Іллінойський університет (Чикаго, США), Лондонська школа гігієни та тропічної медицини (Лондон, Велика Британія).

Більшість закордонних експертів вважають, що головний прогрес в удосконаленні галузі охорони здоров'я у світі на наступні десятиліття будуватиметься не на нових медичних знаннях чи медикаментах, а на розвитку та впровадженні профілактичних програм, спрямованих на населення. Більший акцент робиться на підтримання здоров'я та профрілактику захворювань, оскільки це зменшує витрати на догляд і поліпшення здоров'я населення. Ці зміни створили ряд нових можливостей для фахівців галузі охорони здоров'я, зокрема підвищення кваліфікації у напрямі пропедевтики та профрілактичних заходів.

Інфрормування громадськості про вплив токсичних відходів та забруднюючих речовин на здоров'я зосереджує увагу на забезпечення безпеки громади, здоров'я та безпеки працівників.
Результатом $\epsilon$ зростаючий попит на фрахівців 3 охорони навколишнього середовища, виробничої гігієни та громадського здоров'я.

Дослідження громадського здоров'я зосереджуються більше на здоров'ї жінок та дітей, зловживанні молоддю наркотичними речовинами, при цьому більший акцент робиться на роз'ясненні змін поведінки для зменшення ризику передачі венеричних захворювань (ВІЛ/СНІД), туберкульозу та незапланованої вагітності.

Впровадження дисципліни «Громадське здоров'я» (Public health) у ЗВО за кордоном почалось ще у 2000-х роках у зв'язку з приняттям державних документів у галузі охорони здоров'я. Оскільки фрахівці зі спеціальності «Громадське здоров'я» мають сфреру діяльності відмінну від сорери діяльності звичайного медичного працівника, освіта повинна бути теж відповідною. В іноземних $3 В 0$ існують навчальні спеціальності за освітніми напрямами бакалавра та магістра: «Публічне здоров'я» та «Громадське здоров'я», «Охорона здоров'я», «Епідеміологія та біостатистика», «Промоція здоров'я».

У 2017 р. спеціальність «Громадське здоров'я» вперше з'явилася в Україні та була ліцензована у 2018 р. Ї̈̈ поява викликана необхідністю проведення медичної реформи та підготовки нових кадрів за європейськими стандартами у сфрері управління та охорони громадського здоров'я, впровадження загальнонаціонального принципу «охорона здоров'я в усіх політиках держави».

В Україні підготовка фрахівців у даному напрямку здійснюється за спеціальністю 229 «Громадське здоров'я» (галузь знань - 22 Охорона здоров'я) на трьох ступенях освіти: бакалавр, магістр і доктор фрілософрії. Спеціалізації за даною спеціальністю: «Промоція здоров'я»; «Менеджмент здоров'я»; «Епідеміологія та біостатистика».

У цій сфері працюють як медичні заклади вищої освіти (Національний медичний університет імені О. О. Богомольця, Навчально-науковий інститут медицини Університету «КРОК», Вінницький національний медичний університет ім. М. І. Пирогова, Тернопільський державний медичний університет імені І. Я. Горбачевського, Дніпровський інститут медицини та громадського здоров'я, Харківський національний медичний університет, Львівський медичний інститут), так i ті, що безпосередньо не підпорядковані Міністерству охорони здоров'я (Сумський державний університет, Ужгородський національний університет, Національний університет «Острозька академія», Національний університет 
біоресурсів і природокористування України та Міжнародний класичний університет імені Пилипа Орлика).

Для фрахівця цієї сфери важливо пропагувати дбайливе ставлення до навколишнього середовища, вести активний спосіб життя. Важливими $\epsilon$ комунікативні навички, здатність систематизувати та аналізувати інформацію, розумітися у захворюваннях та симптомах, діяти в екстрених ситуаціях та швидко приймати рішення. В умовах постійного впровадження інноваційних технологій заклади охорони здоров'я, рекреації, реабілітації, туризму, спорту та фрізичної культури потребують кваліфрікованих працівників, які не лише розуміються в області медицини, а й володіють знаннями про новітні підходи вирішення гострих питань. Фахівець з громадського здоров'я повинен вміти аналізувати стан фрізичного та психічного здоров'я окремого індивіда, групи осіб і населення цілої країни. Це людина, яка займається промоцією здорового способу життя, охороною довкілля, стежить за екологічною ситуацією, запобігає травматизму на роботі, під час навчання та відпочинку.

Спеціальність «Громадське здоров'я» забезпечує широкий спектр застосування знань у різних сорерах діяльності, зокрема:

1) сорера профолактичної медицини: планування та впровадження належних профрілактичних заходів, спрямованих на оздоровлення населення; вивчення особливостей прояву та профрілактики інфекційних та неінфекційних захворювань, гігієна (гігієна води та водопостачання, гігієнічні вимоги до планування населених пунктів, виробничих та житлових приміщень, фрізіолого-гігієнічні основи трудового процесу тощо) та санітарія (санітарна охорона джерел водопостачання, оцінка санітарного стану об'єктів, рекреаційних зон тощо);

2) сфрера менеджменту В охороні здоров'я: основи управління, регулювання та контроль фрінансовими, матеріальними та трудовими ресурсами за загальнонаціональним принципом «охорона здоров'я в усіх політиках держави» 3 метою поліпшення громадського здоров'я; підвищення якості лікувально-профрілактичних заходів та раціонального використання ресурсів охорони здоров'я; набуття навичок організації управління закладами охорони здоров'я;

3) сорера медичного праßа та біоетики: вивчення системи норм, що регулюють відносини, пов'язані з організацією, забезпеченням та наданням медичної допомоги/медичних послуг; вивчення основ захисту прав пацієнтів, лікарів, членів їх сімей у галузі медичного права, консультування 3 питань якості медичного обслуговування, існуючого та/або можливого негативного впливу факторів середовища життєдіяльності на здоров'я на індивідуальному та популяційному рівні;

4) сфоера економіки охорони здоров'я: забезпечення соціального захисту інтересів населення в охороні здоров'я завдяки медичному страхуванню; набуття вмінь щодо консультування громадян про безкоштовне надання певного обсягу медичних послуг під час виникнення страхового випадку (порушення здоров'я), консультування $з$ питань оцінки соціально-економічних збитків;

5) сорера екології: дослідження стану довкілля, вивчення екології людини (зокрема впливу чинників навколишнього середовища на функціонування людського організму, цілеспрямоване управління, збереження i поліпшення здоров'я населення), охорона навколишнього середовища, поведінка людини в надзвичайних ситуаціях, застосування засобів та методів щодо покращення здоров'я людини й профрілактики захворювань під дією шкідливих чинників зовнішнього середовища;

6) сорера промоціі (форомування, підтримання, збереження, змічнення) та психологіі здоров'я: вивчення методів щодо особливостей зміцнення та підтримки здоров'я людини, профрілактичні практики у збереженні здоров'я населення, впровадження нових методів та інформаційних ресурсів у пропагуванні здорового способу життя, розвиток та вдосконалення системи комунікаційного менеджменту (інформування населення щодо підтримки, збереження здоров'я тощо) у сорері громадського здоров'я;

7) сочіальна сфера: надання паліативної та хоспісної допомоги (дозволяє покращити якість життя пацієнтів та їхніх сімей, які зіткнулися 3 проблемами смертельного захворювання, шляхом запобігання і полегшення страждань завдяки широкому комплексу медико-соціальних та психотерапевтичних заходів, ранньому виявленню, ретельній оцінці й лікування болю та інших фрізичних симптомів, а також наданню психосоціальної і духовної підтримки); соціальна, психологічна та фрізична реабілітація, набуття навичок у проведенні експертизи працездатності людини, набуття навичок щодо підтримання здоров'я у сорері обслуговування населення (туризм, ресторанний та готельний бізнес, заклади освіти, фрізичної культури і спорту тощо).

Після закінчення закладу вищої освіти фрахівець із громадського здоров'я буде володіти глибокими знаннями у сорері охорони громадського здоров'я та виконувати такі обов'язки, залежно від займаної посади: 
- оцінка стану здоров'я окремої людини, групи осіб, колективу, соціальної групи та суспільства залежно від обставин та умов життя;

- проведення моніторингу та реагування на різноманітні небезпеки для стану здоров'я суспільства, особливо в умовах надзвичайних ситуацій;

- захист навколишнього середовища, умов навчання та праці, контроль за харчовими продуктами, способами відпочинку;

- розробка методів та заходів охорони громадського здоров'я у країні, пропагування здорового способу життя;

- аналіз фрізичного на психічного стану здоров'я;

- проведення профрілактичних заходів з охорони здоров'я;

- проведення заходів щодо уникнення травматизму, спалахів інфрекцій;

- правова підтримка, консультації, управління та економічний аспект у питаннях охорони здоров'я;

- встановлення комунікації в суспільстві у питаннях охорони здоров'я та навколишнього середовища.

Фахівець із громадського здоров'я має широкі перспективи працевлаштування не лише у сфері охорони здоров'я, а і в інших профресійних галузях, таких, як:

- асистент у медичній установі;

- фрахівець із гігієни;

- помічник керівника на підприємствах, в організаціях та установах;

- соціальний працівник;

- консультант з питань епідеміології;

- спеціаліст з санітарної освіти та трудової адаптації;

- інструктор з фрізичної підготовки та реабілітації;

- помічник реабілітолога;

- фрахівець з інклюзивної освіти;

- тьютор для роботи з дітьми з особливими потребами;

- валеолог;

- дезінфректор;

\section{Література}

1. https://tsn.ua/ukrayina/za-30-rokiv-naselennya-ukrayiniskorotitsya-na-20-oon-1364835.html

sergfut@gmail.com
- спеціаліст із медичного страхування;

- експерт з екологічних та техногенних питань;

- інспектор з хімічного та радіаційного захисту;

- викладач охорони здоров'я.

Тому метою розробки і впровадження підготовки фрахівців за освітньою програмою 229 «Громадське здоров'я» на базі Національного університету фрізичного виховання і спорту України $\epsilon$ підготовка молодих перспективних спеціалістів на стику галузей охорони здоров'я, менеджменту, економіки та фрізичної культури і спорту, готових успішно розпочати кар'єру у міжнародних проектах, недержавних організаціях чи урядових структурах політичної, економічної та соціальної діяльності у напрямі охорони здоров'я як окремого громадянина, так і населення України в цілому.

\section{Висновки}

1. Концепція розвитку системи громадського здоров'я в Україні передбачає запровадження у ЗВО за базовими спеціальностями програм 3 науково обгрунтованої профресійної діяльності в сорері громадського здоров'я для забезпечення проведення комплексної оцінки і моніторингу стану здоров'я населення, виявлення фракторів, що впливають на здоров'я населення, здійснення заходів щодо збереження та зміцнення здоров'я населення і оцінювання їх ефективності.

2. Розробка і впровадження підготовки фрахівців за освітньою програмою 229 «Громадське здоров'я» на базі Національного університету фрізичного виховання і спорту України $є$ актуальною і перспективною.

3. Фахівці зі спеціальності «Громадське здоров'я» мають широкі перспективи успішно розпочати кар'єру у міжнародних проектах, недержавних організаціях чи урядових структурах політичної, економічної та соціальної діяльності у напрямі охорони здоров'я.

Перспективи подальших досліджень ми бачимо у розробці освітньої програми 229 «Громадське здоров'я» на основі світового і вітчизняного досвіду можливості впровадження програм здорового способу життя у спортивній галузі.

2. Про схвалення Концепції розвитку системи громадського здоров'я від 30 листопада 2016 р. № 1002-р Київ, https://zakon.rada.gov.ua/laws/show/1002-2016-\%D1\%80\#n8

Надійшла 5.11.2019 